\title{
Marta Koronkiewicz
}

Uniwersytet Wrocławski

\section{Wojaczek wśród najmłodszych}

\begin{abstract}
Wojaczek among the youngest

In the article, the author considers ways in which representatives of the youngest generation of poets refer to the poetry of Rafał Wojaczek, pointing out that, on the one hand, the legend which has grown around this poet's biography is something tempting and difficult at the same time, and on the other hand, in his poetics the young poets find a way to go beyond irony and towards a non-pathetic sublimity, which has a generational significance for them. According to the author, such effects of reading Wojaczek can be found today in poetry of Konrad Góra and, artistically related to him, Kamil Brewiński or Szymon Domagała-Jakuć. Andrzej Sosnowski is pointed out as an important intermediary who offers a refreshing interpretation of the poetry of the author of Inna bajka.
\end{abstract}

Słowa kluczowe: Rafał Wojaczek, Konrad Góra, Szymon Domagała-Jakuć, Kamil Brewiński, forma, młoda poezja

Keywords: Rafał Wojaczek, Konrad Góra, Szymon Domagała-Jakuć, Kamil Brewiński, form, new poetry

Rafał Wojaczek to dla wielu poeta, z którego się wyrasta. Swego czasu na łamach „Dwutygodnika” Aldona Kopkiewicz pisała o zakochiwaniu się w jego poezji w wieku 16 lat i o tym, jak powtórne lektury stanowią wieczne powroty do tego wieku. Pisała też, że w wieku lat 27 nie umie pisać o tej miłości 
bez ironii' ${ }^{1}$ Od momentu publikacji jej tekstu nie minęło wystarczająco dużo czasu, byśmy zasadnie mogli spytać autorkę, czy w późniejszym wieku to poczucie się zmienia. Ironia i przymrużenie oka, z jakim wielu mówi o poezji Wojaczka, skrywają często zawstydzenie, rodzaj zażenowania sobą samym z przeszłości, z okresu, w którym ,przez Wojaczka”, jak przez ospę wietrzną, przechodzimy. Właśnie dlatego to młodym, najmłodszym poetom szczególnie trudno odwoływać się do twórczości Wojaczka, trudno do niego przyznawać. Podczas gdy starszy twórca legitymizuje takie odniesienie własnym dorobkiem, statecznym wiekiem, zestawem „poważnych” inspiracji i nabytym ciężką pracą prawem do ekscentryzmów czy idiosynkrazji, młodego autora sięgającego po motto z Wojaczka posądzić można o to, że nie wydoroślał, nie porzucił młodzieńczych fascynacji, ulega legendzie. To oczywiście obraz grubymi nićmi szyty, dobrze chyba jednak oddający rodzaj dylematu stojącego przed młodymi twórcami. Młoda poezja wstydzi się kategorii, którymi posługują się zwykle autorzy tekstów o Wojaczku - a jednak Wojaczek nie jest zupełnie wśród najmłodszych nieobecny. Chciałabym zatem spytać: dlaczego najmłodsi twórcy uważają, że - mimo ryzyka - warto do Wojaczka sięgać; do czego go potrzebują i dlaczego podejmują wyzwanie?

Spróbujmy więc wskazać sposoby istnienia Wojaczka w wierszach i książkach młodych poetów. Najpierw zwróćmy się jednak do autora, który - dzięki swojemu wpływowi na kształt współczesnej poezji - stanowi rodzaj ważnego pośrednika, a mianowicie do Andrzeja Sosnowskiego. Jacek Gutorow w swoim ważnym szkicu na temat poezji Rafała Wojaczka, pomieszczonym w tomie Niepodległość głosu, odwołał się do pewnej frazy z wiersza Sosnowskiego. Pisząc do niej przypis, poszerzył go o dość luźne skojarzenie, którego - indagowany w tym temacie niemal 10 lat po wydaniu książki² - nie pamiętał wystarczająco, żeby pokusić się o interpretacyjny ciąg dalszy. Przypis brzmiał:

Interesujące byłoby prześledzenie linii poetyckiej Leśmian-Sosnowski z uwzględnieniem Wojaczka. Samą linię nakreślił już Marian Stala, wydaje mi się jednak, że to właśnie Wojaczek, a nie na przykład Karpowicz, jest tym poetą, przez którego Sosnowski czyta Leśmiana ${ }^{3}$.

Trudno powiedzieć, jak dokładnie ten ,pryzmat” Wojaczka miałby działać, nie ma jednak wątpliwości, że autor Sezonu pozostaje dla Sosnowskiego jedną z kluczowych figur; i to figurą łączącą go z dłuższą literacką tradycją, biegnącą - być może - właśnie przez Leśmiana. Zostawmy jednak w tym miejscu kwestie poetyckich zapośredniczeń. Sosnowski zmienia obraz i pozycję Wojaczka, przywołując go w szkicach i rozmowach; wpisując go w nowe, odległe od zwyczajowych konteksty. W tytułowym eseju z tomu Najryzykowniej

1 A. Kopkiewicz, Reprint Wojaczka jak kaseta Nirvany, http://www.dwutygodnik. com/artykul/5292-reprint-wojaczka-jak-kaseta-nirvany.html [dostęp: 28.05.2017].

2 W korespondencji prywatnej.

3 J. Gutorow, Niepodległość głosu. Szkice o poezji polskiej po 1968 roku, Kraków 2003, s. 101. 
Sosnowski przypomina dwa wiersze Wojaczka; ten sam zestaw służy mu za punkt odniesienia w wykładzie wygłoszonym w ramach Pracowni Poetyckiej Silesius i wydanym - wraz z sytuacjonistycznie inspirowanym manifestem Darka Foksa - przez wydawnictwo Warstwy ${ }^{4}$. Te utwory Wojaczka to Prośba i Ranny wiersz. Pierwszy z nich warto przytoczyć w całości (zwłaszcza że to nie jedyny wiersz tego autora opatrzony takim tytułem):

Dać mi miotłę bym zamiótł publiczny plac

Albo kobietę bym ją kochał i zapładniał

Dać mi ojczyznę bym opiewał

Pejzaż lub ustrój lżył czy chwalił rząd

Przedstawić mi człowieka bym ujrzał jego wielkość

Czy nędzę i opisał w ciekawych słowach

Wskazać mi zakochanych bym się wzruszył

Posłać mnie do szpitala. Na komunalny cmentarz

Urządzić mi teatr igrzyska sportowe

Wojnę żniwa we wsi festyn w mieście

Albo nauczyć mnie prowadzić samochód pisać na maszynie

Zmusić do nauki języków czytania gazet

A ostatecznie dać mi choć wódki żebym pił

I potem rzygał bo poetów należy używać

W Najryzykowniej Sosnowski zestawia ten wiersz z Holderlinowskim pytaniem: „Wozu Dichter?”, „I cóż po poecie w czasie marnym?”, pisząc: „naszemu poecie najbliższa musi być jakaś trzecia i najdalsza strona spraw jako widmowy oddźwięk i odsłuch zaginionej realności życia"s. Autor poems skonstruował na własny użytek swoisty zbiór czy katalog „poszukiwaczy życia” - życia w jakimś sensie „prawdziwego”, niewypaczonego przez rozpad i wynaturzenia komunikacyjnych form; do tego zestawu należą Walter Benjamin, Artur Rimbaud i Guy Debord, ale również Rafał Wojaczek. Rolę poszukiwaczy życia opisują z kolei dobrze słowa, które Sosnowski wykorzystał w kontekście Roussela, autora - można by powiedzieć - umierającego pełnią życia: „Z reguły metodycznie (i nadzwyczaj obsesyjnie): poszukując euforycznej pełni w pisaniu, zamaszystym gestem wypisywał się z życia". Sytuacjonistyczne wątki, które pojawiają się szczególnie w późniejszych pracach Sosnowskiego, mają zatem wiele wspólnego z jego zainteresowaniem Wojaczkiem - chodzi o różne realizacje pewnego archetypu czy wzorca - i to połączenie, sama jego możliwość, niejako toruje drogę młodszym, zwłaszcza zaangażowanym poetom.

Rzadko się to podkreśla, jednak Sosnowski stanowi jeden z głównych punktów poetyckiego odniesienia dla jednego z najlepszych twórców młodego pokolenia - Konrada Góry. Poważna literacka relacja tego ostatniego do

4 A. Sosnowski, D. Foks, Pracownia poetycka Silesius, Wrocław 2015.

A. Sosnowski, Najryzykowniej, Wrocław 2007, s. 9.

6 Ibidem, s. 138. 
twórczości Rafała Wojaczka legitymizuje się właśnie postawą Sosnowskiego, to starszy pośrednik pozwala zneutralizować zarzuty o młodzieńczość inspiracji. A zarzut taki mógłby się pojawić - Górze nieobce są wspomniane wyżej wstydliwe rejestry, fascynacja legendą; zdał z nich sprawę w prozie pomieszczonej w biuletynie wrocławskiego BWA Awangarda:

[...] i tak wtaczałem się nocą czy dniem do miasta, którym starałem się gardzić, i którego częścią coraz mocniej byłem: jak głupki poszliśmy z Czahą na grób Wojaczków, Andrzej, lekarz, umarł niewiele wcześniej, nie można było unieść płyty z nad pierwszego brata, żeby dosunąc doń drugiego: skremowano więc jego ciało i wepchnięto urnę najdalej, jak się dało: myślałem o tym, jak o próbie montażu lampki w jakiejś osypanej grocie, żeby choć oświetlić pierwsze jej metry, skoro nie można dostać się dalej, albo, jeszcze bardziej, o dostarczaniu światła dziecku, które utknęło w studni albo spuście gnojownika i jeszcze się nie zaczadziło: na grobach braci spotkaliśmy nieformalną wdowę po Andrzeju, przynosiła nam potem słoiki na ogórki na skłot, bo nie wiem dlaczego, powiedziałem jej, że tego potrzebujemy najbardziej. Stała tam też sztofka wódki z liściem jesionu na wierzchu, jakiś dureń przychodził tam pić z Rafałem. Było tego za mało i za daleko, żeby po to jeździć, ale opcja czterdziestu czy pięćdziesięciu gram jesionówki jako konsumpcyjna ostateczność zagnieździła mi się we wspomnieniach, których próbowałem dokonywać na przykład ustami ${ }^{7}$.

Od razu sprostujmy: Andrzej Wojaczek był oczywiście aktorem, nie lekarzem $^{8}$. Sam kronikarski błąd potwierdza jednak doskonale, że dla Góry istotniejsza niż ta narracja jest poważna poetycka inspiracja; ostatecznie bowiem mniejsza z legendą, która Górę, poetę z Wrocławia, o barwnej biografii i nieuporządkowanej codzienności będzie oczywiście kusić, ale z której, siłą rzeczy, mając lat ponad 30, wyrośnie. Choć wpływ Wojaczkowej dykcji daje się wychwycić w jego książkach od samego początku, dopiero w ostatniej to odniesienie staje się zupełnie jawne. Siła niższa (full hasiok) została bowiem opatrzona dwoma mottami, jednym z nich jest wypowiedź Rafała Dutkiewicza, prezydenta miasta Wrocławia, drugim zaś przytoczony w całości wiersz Wojaczka Modlitwa szarego człowieka. To co jednak najbardziej zbieżne między oboma poetami, to sposób widzenia relacji między elitaryzmem formy a egalitaryzmem wiersza. Do tego wątku powrócę.

Bezpośrednio pod wpływem Góry pozostają dwaj młodsi poeci, których autor Requiem dla Saddama Husajna niejako wskazał i namaścił, pisząc blurby do ich tomów. Myślę tu o Szymonie Domagale-Jakuciu i Kamilu Brewińskim, debiutujących odpowiednio w 2014 i 2013 roku'. O inspiracjach Wo-

7 K. Góra, O co kaman, http://konrad-gora.liternet.pl/tekst/o-co-kaman [dostęp: 27.05.2017].

8 Rolę lekarza - psychiatry - zagrał jednak w filmie "Wojaczek" w reżyserii Lecha Majewskiego; być może stąd pomyłka.

9 K. Brewiński, Clubbing, Kraków 2013; Sz. Domagała-Jakuć, Hotel Jahwe, Łódź 2014. 
jaczkowych u pierwszego z nich wspominała Anna Kałuża ${ }^{10}$, warto jednak podkreślić to zapośredniczenie u Góry, dobitnie wskazane w wierszu zatytułowanym Konrad (prawdziwy bohater wobec wrogów rozpoznaje los swój i los ich lecz to nie czyni z niego trupa przeciwnie ożywia bardziej niż trwanie w słabości chtodne widzenie):

Ty jesteś Góra ja jestem Dół

Krwi kwiatu nie psujesz boś dobrze wymierzył księżyc

Mnożą się listowia twoje pośród paroksyzmów

Są też drzwi jak wiara otwierasz je a wygląda zza nich znośny obywatel

to ja przysięgam to ja i wiem że mnie poznajesz jak mięso psu przyznaję się do kłów i do trocin

Pierwszy wers w wierszu Jakucia jest parafrazą otwarcia słynnego Wojaczkowego Krzyża:

Ja jestem pozioma

Ty jesteś pionowy

Ty jesteś góra

Ja jestem dolina

$[\ldots]$

Ja jestem pozioma

Ale nie zawsze

Ty jesteś pionowy

Ale do czasu

Ja jestem pionowa

Góra orgazmu

Ty jesteś pionowy

Przy mnie

Po części w ramach żartu z nazwiska Domagała wpisuje w ten erotyczny kontekst Konrada Górę; ustanawiając tym samym rodzaj homoerotycznej poetyckiej relacji, samego siebie podporządkowując i umniejszając, sytuując w roli efeba, wobec Góry zaś stosując cały wachlarz Wojaczkowych motywów i rekwizytów: bohater, kwiat, krew, księżyc, nawet ten „znośny obywatel” brzmi bardziej latami sześćdziesiątymi, niż społeczeństwem obywatelskim.

Domagała-Jakuć najszerzej chyba ze wszystkich wymienionych eksploruje język i obrazowanie Wojaczka, splatając wątki erotyczne i religijne, somatyczne i autotematyczne; realizując pewien model obrazoburstwa znany z poezji autora Innej bajki. Najciekawsze jest jednak to, co dzięki tej pracy udaje mu się do wiersza włączyć, a co, wydawałoby się, powinno ten wiersz uniemożliwić: tematy z prasy bieżącej, najbardziej wymęczone newsy (np. Matka Madzi); utrzymanie się „na nucie najwyższej”, umiejętnie skonstruowana żarliwość pozwala mu przedstawiać te tematy z autentycznym przejęciem. Zaangażowanie Jakucia staje się przez to wyraźnie interwencyjne, choć

10 A. Kałuża, [wypowiedź w ankiecie], „Odra” 2015, nr 6. 
jego wiersze nie mają nic wspólnego z poezją agitacyjną, realizując - jak pisze Kałuża - odmianę dyskursu „histeryczno-psychiatrycznego”.

Kamil Brewiński zaś - jako bodaj pierwszy od bardzo dawna - staje w szeregu poetyckich działkowiczów, w swoje blokersko-narkotyczne wizje wplatając raz po raz najbardziej poetycki z kwiatów:

oddal palec od wody w której płynie róża

lub okno uchyl zanim zapomnisz o dłoniach

nie patrz w rozgrzane oko gdzie zakwitła róża

zanim zgęstniała w popiół lżejszy od powietrza

$[\ldots]$

lustrzane płatki róży nosiłaś na udach

a dj brewynsky tę nutę scratchował

i przegryzioną wargą rybak kosił księżyc

a dj brewynsky nutę tę scratchował

$\mathrm{W}$ innym wierszu:

w kałuży swojego cienia i z różą w ustach budzę się tam gdzie kres swój ma ponowoczesność w kałuży swojego cienia i z różą w ustach jak światełko w tunelu wyglądam rażąco

I może jeszcze bardziej dobitny przykład, w rodzaju niemęskoosobowym:

powtarzam: jesteśmy czyste jak cudze łzy

na swoją obronę mamy miednice róże

kiedy próbujemy zasnąć przez szczelne okna

dłoń szorstka i gęsta jak las stapia nam stawy

w koleiny wyra upycha ciekły księżyc

To tylko mały wybór, o wielości i poetyckiej proweniencji tych róż pisał w swojej recenzji z Clubbingu Adam Wiedemann, jako źródło wskazując przede wszystkim wczesnego Rymkiewicza ${ }^{11}$. Wydaje się jednak, że bliski wpływ twórczości Góry na Brewińskiego może sugerować Wojaczkowe pośrednictwo - potwierdzane jeszcze charakterystycznym, wyzyskiwanym przez Brewińskiego, napięciem między przeestetyzowaniem i brutalnością.

Opozycję estetyzmu i brutalności można opisać też jako napięcie między elitaryzmem formy a politycznym egalitaryzmem - szalenie istotne dla tak naszkicowanej linii poetów, którzy przyznają się do anarchistycznej, anarchicznej czy anarchizującej perspektywy, a jednocześnie celują w klasyczne formy i warsztatową precyzję, wiązaną tradycyjnie z dykcją wysoką. Program zespolenia tych dwóch elementów wynika, jak się zdaje, przede wszystkim ze zrozumienia, iż rzeczywistość społeczna ma również charakter formalny, że

11 A. Wiedemann, ...co to jest róża?, http://www.dwutygodnik.com/artykul/4661-coto-jest-roza.html [dostęp: 28.05.2017]. 
zmiana społeczna, rewolucja - jest zmianą pewnej formy ${ }^{12}$. O tym, że Wojaczek to naraz dobry i zły wzór może świadczyć taka wypowiedź Góry:

Ludzie są jakoś, nie wiem, na etapie percepcji Grochowiaka? Może Stachury? (śmiechy) Dzieci dużo Stachury czytają. Choć dzieci nie czytają nic już obecnie, tylko życie je interesuje, żadna oprawa tego życia nie wchodzi w rachubę ${ }^{13}$.

Zły - bo przecież często wymieniany jest jednym tchem ze Stachurą, a to już naprawdę nie wypada. Dobry, bo niewielu bardziej świadomie życie oprawiało, wyprawiało, osaczało, by tę jego resztkę, o której pisze Sosnowski, jakoś znaleźć. Sosnowski i Góra to poeci procedur (podobnie jak przytoczony już Roussel) - Tymoteusz Karpowicz pisał, że Wojaczek organizował sobie życie za pomocą nakazów utrudniających. Tylko najwyższe formy formy dają rodzaj wolności: pozwalają powiedzieć coś naprawdę (jak mówił Georges Perec), a może i przeżyć.

Można powiedzieć więc, że najmłodszym Wojaczek potrzebny jest z trzech powodów. Po pierwsze: ze względu na pewną intensywność, której szukają, pewną żarliwość, której tradycję muszą ostrożnie dobierać. To euforyczna intensywność opisana przez Sosnowskiego, a więc również intensywność Rimbauda czy Deborda z jego życiem przeżywanym z momentu na moment. Wskazuje ona pewien model zaangażowania - taki, który odciąć musi się od tego, co wyśmiane ze względu na schematyczność, sztywność, rygory bardziej instytucjonalne niż proceduralne. Góra i poeci z jego linii szerokim łukiem ominą patetyzmy poezji stanu wojennego, choć będą chcieli eksperymentować ze wzniosłością ${ }^{14}$, choć będą uciekać od ironii Brulionowców. Wojaczek okazuje się dla nich trudnym, ale potrzebnym źródłem patosu, który się nie zużył; ironii, która nie unieważnia. Jacek Gutorow wskazuje na barokową proweniencję tej ironii, jej paradoksalny charakter ${ }^{15}$. W tej formie nie jest ona sprzeczna z potrzebą intensywności właśnie, tak jak rozumieli ją sytuacjoniści: „intensywność każdego [przeżywanego - M.K.] momentu niszczy pamięć, czyli to, co zwykle krępuje twórczą wyobraźnię"16. U Wojaczka tego rodzaju intensywność ma charakter transgresyjny, w linii Góry - zapożyczonego u Sosnowskiego - staje się źródłem i metodą oporu. Wydaje się jednak,

12 Por. na ten temat C. Levine, Forms: Whole, Rhythm, Hierarchy, Network, Princeton 2015.

13 Żadna reprezentacja. Z Konradem Górą, Szczepanem Kopytem i Kirą Pietrek rozmawia Aldona Kopkiewicz, http://www.dwutygodnik.com/artykul/4535-zadnareprezentacja.html [dostęp: 28.05.2017].

14 Pisał o tym przekonująco Paweł Kaczmarski (Egzaltacja i nowe możliwości [o jednym wierszu Szczepana Kopyta]), http://www.praktykateoretyczna.pl/index.php/ pawel-kaczmarski-egzaltacja-i-nowe-mozliwosci-o-jednym-wierszu-szczepana-kopyta/) [dostęp: 28.05.2017].

15 Por. J. Gutorow, op.cit., s. 93-101.

16 Constant, Lecture Given at the ICA London (1963). Cyt. za: M. Wark, 50 Years of Recuperation of the Situationist International, New York 2008. 
że mają z sobą wiele wspólnego: prekursorska kontrkulturowość Wojaczka staje się tutaj jeszcze wyraźniejsza.

Po drugie: u Wojaczka, w wierszach takich jak przytaczana Prośba, młodzi autorzy znajdują rodzaj społecznego wstydu poety, który dzielą i tematyzują, wstydu za własną nikłą przydatność: to oczywiście wątek znany i zawsze obecny, jednak jego szczególne, bardzo „konkretne” oblicze brane od Wojaczka interesuje Górę czy innych zaangażowanych. Wojaczek mówi, że jest poetą, kiedy bije i pluje (Piosenka o poecie), mizerne są jednak pięści poematu, a gest to - jak mówi - dziecinny. Mówi, gdzie indziej, że poecie wszystko wolno. I to napięcie: między wszystko wolno a nic się nie da organizuje też przestrzeń dzisiejszego myślenia o performatywności poezji. Konrad Góra tak odniósł się do tego problemu:

Ja na przykład zakładałem całkiem poważnie, że skoro robotnika można wypierdolić z roboty za to, że powie o sobie, że jest anarchistą, to ja będę za niego mówił, że jestem anarchistą. Bo jestem, tylko że mnie nie ma kto z roboty wypierdolić, bo jak. Jak mnie pytają, to najczęściej przedstawiam się, że jestem bezrobotny. To jest taka brutalna sprawa. Ale po diabła ja miałbym nie być anarchistą, po co, w ramach jakiej wdzięczności światu. Ja mogę być anarchistą, taki nie wiem, robotnik, taka pielęgniarka, ukraińska pomoc domowa, to oni sobie w duchu mogą być anarchistami, a ja mogę być po prostu anarchistą. Co, na chuja mi naskoczą? Nie naskoczą. Co mi zrobią? Na Festiwal Miłosza mnie zaproszą, tfu $^{17}$.

Rafał Wojaczek szukał upodlonych wcielen - by z nich się przeanielić. Góra o przeanieleniu nie myśli, natomiast tak jak Wojaczek wciela się i udziela głosu tym, którzy w różny sposób ów głos mają ograniczony; planując czy projektując przeanielenie na wspólnotę, kolektywnie, transponując Wojaczkową wrażliwość na swoją polityczną potrzebę działania poetyckiego.

„Na Festiwal Miłosza go [Górę - M.K.] zaproszą”, bo jest „dobrym poetą”. Formalne popisy to pozornie sposób wkupienia się w pewien obieg, część kreacji poetyckiej wszechmocy. Góry „bycie poetą” to równocześnie anarchiczna wolność oraz panowanie nad formami. Jednak w gruncie rzeczy obie strony równania są tym samym: poeta stoi w miejscu, w którym nie jest zobowiązany do żadnej formy (społecznej, politycznej), w którym obserwuje formy istniejące, ale ma wolność ich obracania, modyfikowania, nicowania i tworzenia nowych (za pomocą form literackich).

Po trzecie wreszcie: lektura Wojaczka to wstydliwa przyjemność, guilty pleasure, $\mathrm{w}$ tym sensie, $\mathrm{w}$ jakim powielanie pewnych konwencji może być przyjemne i przez tę przyjemność - estetycznie istotne. Realizowany przez niego stereotyp poetyckości, bycia poetą, może być dzisiaj, po panironicznych latach dziewięćdziesiątych, odbierany jako trochę niezręczny; jest jednak pokoleniowo potrzebny. Stanowi pewne residuum, resztkę tego, co w badaniach nad dziełem Wojaczka tak często bywa określane słowem „czystość”: czysty głos, czysty ton; w owej resztce Sosnowski dojrzał także u tego wybitnie

\footnotetext{
17 Żadna reprezentacja....
} 
śmiertelnego poety margines życia (oblężonego, usuwanego, wypisywanego). I ten czysty głos poety okazuje się jakoś niezastąpiony. Wojaczek może być stereotypowy, ale jest stereotypem „formacyjnie” potrzebnym.

$\mathrm{Z}$ tą ostatnią kwestią łączy się wątek, który chciałabym otworzyć na zakończenie, otworzyć i nie zamykać, bo nie wiem jeszcze, czym jest w istocie. Wątek ów skupia się w haśle: Tomek Pułka. Pokolenie najmłodszych poetów i czytelników poezji, roczników osiemdziesiątych i dziewięćdziesiątych, ma swoją legendę, swojego młodo zmarłego genialnego twórcę. Pułka zmarł w roku 2012 we Wrocławiu, tonąc w niewyjaśnionych okolicznościach w Odrze. Przed śmiercią zdążył wydać cztery książki poetyckie, pośmiertnie ukazały się jeszcze dwie. Był jednym z ciekawszych spośród poetów ewidentnie zapożyczonych u Sosnowskiego. Żył intensywnie i głośno, pisał niezrozumiale, ale z przebłyskami geniuszu: też jeśli chodzi o nagle stosowane tradycyjne formy, niespodziewany klasycyzm. Pułka jest jednym z bohaterów Sity niższej (full hasiok), jest bohaterem środowiskowych sporów o to, kto bardziej, kto lepiej, kto bliżej go znał. W jakim stopniu miejsce, które zajmie, zostało uformowane, choćby nieświadomie, na kształt tego ostatniego genialnego samobójcy? W jakim zakresie młodzi poeci będą używać Pułki, tak jak Wojaczka? To pytania ciągle otwarte.

\section{Bibliografia}

Brewiński K., Clubbing, Kraków 2013.

Domagała-Jakuć Sz., Hotel Jahwe, Łódź 2014.

Góra K., $O$ co kaman, http://konrad-gora.liternet.pl/tekst/o-co-kaman [dostęp: 27.05.2017].

Gutorow J., Niepodległość głosu. Szkice o poezji polskiej po 1968 roku, Kraków 2003.

Kaczmarski P., Egzaltacja i nowe możliwości (o jednym wierszu Szczepana Kopyta), http:/www.praktykateoretyczna.pl/index.php/pawel-kaczmarski-egzaltacja-i-nowe-mozliwosci-o-jednym-wierszu-szczepana-kopyta/ [dostęp: 28.05.2017].

Kopkiewicz A., Reprint Wojaczka jak kaseta Nirvany, http://www.dwutygodnik.com/ artykul/5292-reprint-wojaczka-jak-kaseta-nirvany.html [dostęp: 28.05.2017].

Levine C., Forms: Whole, Rhythm, Hierarchy, Network, Princeton 2015.

Sosnowski A., Foks D., Pracownia poetycka Silesius, Wrocław 2015.

Sosnowski A., Najryzykowniej, Wrocław 2007, s. 9.

Wiedemann A., ...co to jest róża?, http://www.dwutygodnik.com/artykul/4661-co-to-jest-roza.html [dostęp: 28.05.2017].

Żadna reprezentacja. Z Konradem Góra, Szczepanem Kopytem i Kira Pietrek rozmawia Aldona Kopkiewicz, http://www.dwutygodnik.com/artykul/4535-zadna-reprezentacja.html [dostęp: 28.05.2017].

Wark M., 50 Years of Recuperation of the Situationist International, New York 2008. 